evincing the wonderful sagacity and perception of the dogs, M. Léonard invited the writer to play a game of dominos with one of them. The younger and slighter animal then seated himself on a chair at the table, and the writer and M. Léonard placed themselves opposite. Six dominos were placed on their edges, in the usual manner, before the dog, and a like number before the writer. The dog, having a double number, took it up in his mouth, and put it in the middle of the table: the writer placed a corresponding piece on one side; the dog immediately played another correctly, and so on till all the pieces were engaged. Other six dominos were given to each, and the writer intentionally placed a wrong number. The dog looked surprised, stared very earnestly at the writer, and at length growled, and finally barked angrily; finding that no notice was taken of his remonstrances, he pushed away the wrong domino with his nose, and took up a suitable one from his own pieces, and placed it in its stead! The writer then played correctly, the dog followed, and $\dot{w}$ on the game. Not the slightest intimation could have been given by $M$. Léonard to the dog; his play must bave been entirely the result of his own observation and judgment. There was no trickery, no mesmerism here. It should be added that the performances were strictly private; no gratuity was allowed even to the servant. M. Léonard is a gentleman of independent fortune, and the instruction of his dogs has been taken up merely as a curious and amusing investigation.

\section{PUBLICATION OF SCIENTIFIC PAPERS BY THE}

LONDON COLLEGE OF SURGEONS.

\section{To the Editor of The Lancet.}

SIR :-By direction of the president I transmit to you the inclosed, and request the insertion thereof in your Journal. I am, Sir, your most obedient servant,

Edmund Belfour, Sec.

Royal College of Surgeons, London, Sept. 6, 1841.

The council proposing to publish, in the course of the ensuing year, a volume, to be entitled "Transactions of the Royal College of Surgeons in London," invite, from the members of the college and other scientific persons, communications relating to the improvement of anatomical and surgical science.

The subjects proposed to be included in this publication are specified in the follow. ing extract from the ordinances of the college :-

“The Transactions shall consist of Oriyinal Communications on Surgical subjects; Collegial and Jacksonian Prize Disserta- tions, deemed of sufficient originality and merit; Original Memoirs on Human Anatomy; Original Memoirs on Comparative Anatomy; Anatomical Monographs of rare Animals, dissected in the Museum of the College; Explanations of, and Commentaries on, important Preparations in the Museum, with illustrative Plates; Statistical Reports from Hospitals."

It is requested that papers intended for publication in this volume may be trans. mitted to the president, at the college, on or before the 1st of May, 1842 .

July 28, 1841.

$$
\text { Edmund Belfour, Sec. }
$$

VACCINATION ACT, No. 2.

Anno Quarto and Quinto Victoria Regina. Cap. 32. An Act to amend an Act to extend the Practice of Vaccination. 21 st June, 1811.

I. Expenses of Vaccination to be defrayed out of the Poor Rates.-Whereas an Act was passed in the fourth year of the reign of her present Majesty, intituled $A n$ Act to extend the Practice of Vaccination; but no express provision was thereby made for defraying the expenses of carrying the same into execution; be it therefore declared and enacted by the Queen's most excellent Majesty, by and with the advice and consent of the Lords spiritual and temporal, and Commons, in this present Parliament assembled, and by the authority of the same, That it shall be and be deemed to have been lawful for the guardians of every parish or union in England and Ireland, and the overseers of every parish in England, by whom the contracts for vaccination may respectively be or have been made under the provisions of the said Act, to defray the expenses incident to the execution of the said Act out of any rates or monies which may come or may have come into their hands respectively for the relief of the poor.

II. Vaccination declared not to be Parochial Relief.-And be it further declared and enacted, That the vaccination, or surgical or medical assistance incident to the vaccination, of any person resident in any union or parish, or of any of his family, under the said Act, shall not be considered to be parochial relief, alms, or charitable allowance to such person, and that no such person shall by reason of such vaccination or assistance be deprived of any right or privilege, or be subject to any disability or disqualification whatsoever.

** This Act, although passed in the last Parliament, was only printed and issued to members on the first day of the present session. 